\title{
NOTE
}

\section{Low fractions of active bacteria in natural aquatic communities?}

\author{
Erik M. Smith*, Paul A. del Giorgio \\ Dépt des sciences biologiques, Université du Québec à Montréal, CP 8888, succursale Centre Ville, Montréal H3C 3P8, Canada
}

\begin{abstract}
The notion that a significant fraction of individual cells within natural bacterial assemblages is not actively engaged in cellular metabolism, although not a new idea, remains fairly contentious. Different approaches for probing the metabolic activity of individual cells often yield widely divergent estimates of the proportion of active cells, with some methods suggesting very low levels of individual cell activity. We comment on 2 aspects of the current discussions regarding cell-specific activity in natural bacterioplankton. First, the apparent perception that most aquatic bacteria must be active is not uniformly supported by the data. In a systematic survey of the microautoradiography literature, for example, only 4 out of 23 studies reported a mean proportion of active cells in natural communities that was greater than $50 \%$, and the mean across all such studies was $30 \%$. Second, we propose that the problem of describing bacterioplankton single-cell activity is best approached from the viewpoint that there is a nested hierarchy of physiological states within bacterial communities. The lack of agreement among various methods points to the large range of criteria possible for describing metabolic activity in bacteria. In this regard, the discrete, and over-simplistic, notion of 'active' versus 'inactive' is not particularly useful and should be replaced by a conceptual model in which there exists a continuum of possible single-cell activities.
\end{abstract}

KEY WORDS: Bacteria $\cdot$ Cell-specific activity $\cdot$ Physiological diversity $\cdot$ Methodological approaches

Resale or republication not permitted without written consent of the publisher

An important goal of microbial ecology is to understand the variability in bacterial rate processes within, and across, aquatic communities. One frustration in this attempt has been the fact that such processes seldom relate well to total abundances of bacteria, which are typically rather invariant. This has led to the development of a number of different techniques for probing the activity of individual cells within the assemblage of total bacteria. Across a range of aquatic ecosystems, a non-trivial and often dominant fraction of the bacterial assemblage is typically unresponsive to at least some of these assays (Sherr et al. 1999, del
Giorgio \& Bouvier 2002). This suggests that either these methods are ineffective in describing bacterial activity, or that many bacterioplankton cells are indeed dormant or have very low levels of cellular activity.

The hypothesis that low levels of cellular activity within natural bacterial assemblages are not uncommon is not new. It has been over 2 decades since Stevenson (1978) first proposed that the physiological state of a significant portion of aquatic bacterioplankton can best be described as dormant. Indeed, there is substantial literature devoted to dormancy and the physiology of 'starvation survival' by bacteria (Morita 1997). Stevenson (1978) originally remarked that '[the] paucity of physiological data suggesting a dormant state for bacteria in the water column is not surprising: it borders on heresy to suggest that bacteria in this environment are not active.' While the number of published accounts of single-cell activity within the bacterioplankton has increased appreciably (Joux \& Lebaron 2000), resistance to reports of large fractions of relatively inactive bacteria within natural communities continues to the present day.

One method in particular has been at the center of much of the recent debate over the distribution of cells with different levels of metabolic activity. It involves the use of the fluorogenic tetrazolium dye, 5-cyano-2, 3 ditolyl tetrazolium chloride (CTC). In theory, bacterial cells that take up and reduce CTC to its fluorescent formazan (CTC+ cells) have an active electron transport system (ETS). As activity within the ETS is essential to cellular respiration (Packard 1985), these cells are thus thought to be 'actively respiring' (Rodriquez 1992). Although abundances of CTC+ cells in natural samples tend to be well correlated to measures of either bacterial production (e.g. del Giorgio et al. 1997, Sherr et al. 1999) or respiration (Smith 1998), the proportion of total cells scored as CTC+ tends to be low, generally less than $20 \%$ and sometimes less than just a few percent. It is precisely these low proportions that 


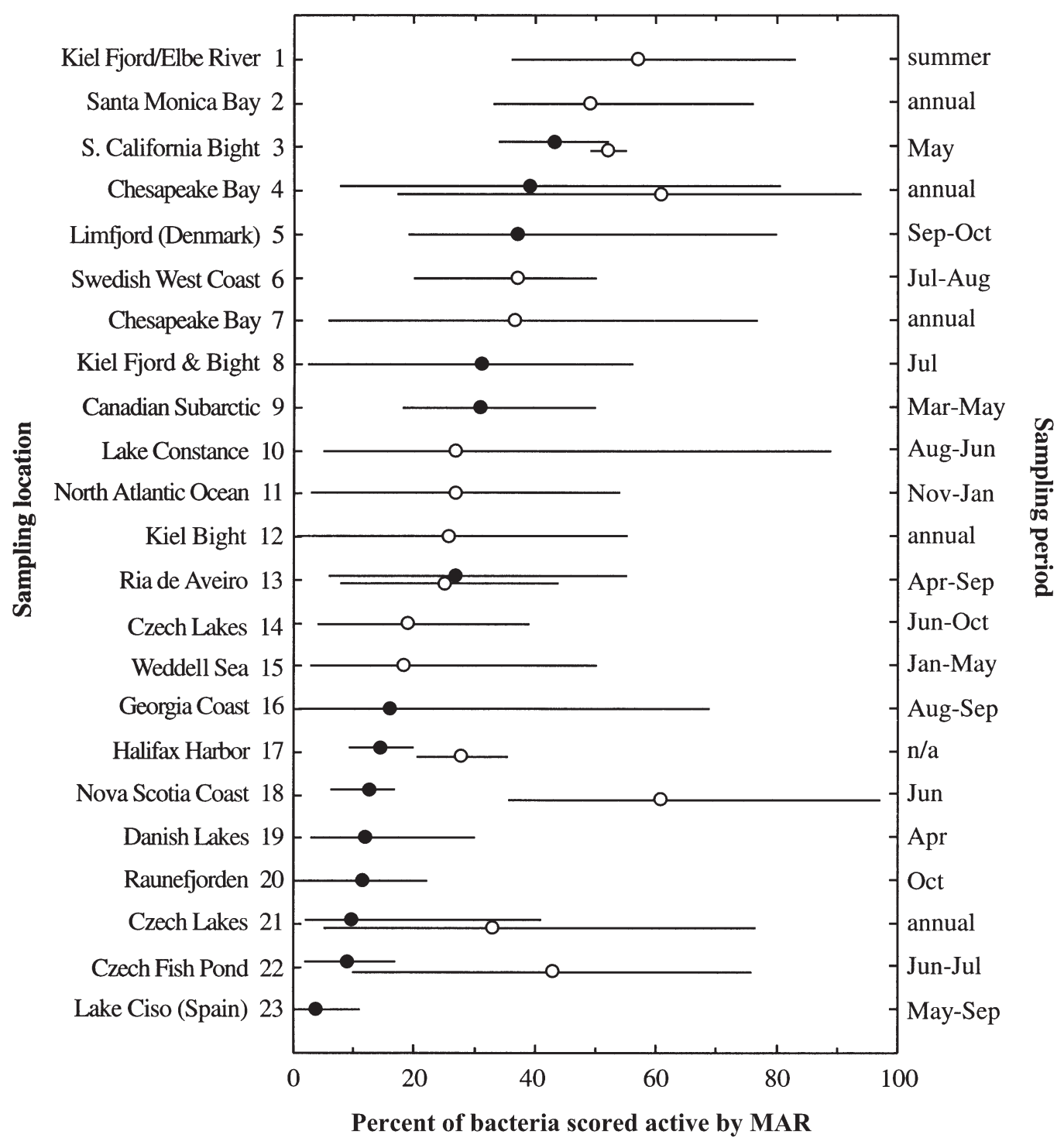

Fig. 1. Studies of natural bacterioplankton communities. Mean and range of \% bacteria scored as active by microautoradiography (MAR). Open symbols are studies using amino acid(s) as tracer; closed symbols are studies using thymidine as tracer. Data sources are: 1. Ullrich et al. (1996); 2. Karner \& Fuhrman (1997); 3. Fuhrman \& Azam (1982); 4. Tabor \& Neihof (1984); 5. Riemann et al. (1984); 6. Hermansson \& Dahlback (1983); 7. Baily et al. (1983); 8. Meyer-Reil (1978); 9. Bunch \& Harland (1990); 10. Simon (1985); 11. Hoppe \& Gocke (1993) and Buck et al. (1996); 12. Hoppe (1977); 13. Almeida et al. (2001); 14. Nedoma et al. (1994); 15. Grossmann (1994); 16. Pedros-Alio \& Newell (1989); 17. Novitsky (1983); 18. Douglas et al. (1987); 19. Marcussen et al. (1984); 20. Tuomi et al. (1995); 21. Straskrabova \& Simek (1984); 22. Šimek et al. (1989); 23. Garcia-Cantizano et al. (1994)

have motivated much of the criticism of CTC as a means of determining activity in bacterial cells.

A defense of the CTC method is not the objective of this Note. While the use of this method has grown over the last several years (e.g. Sherr et al. 1999, Jugnia et al. 2000, Haglund et al. 2002), there have also been a number of studies highly critical of CTC as a means of distinguishing metabolically active cells (e.g. Ullrich et al. 1996, 1999, Karner \& Fuhrman 1997, Servais et al. 2001). These latter studies have raised several legiti- mate methodological concerns about the use of CTC, and it could well be that the method is eventually improved, or even replaced by other more effective indices of single-cell activity. Instead, we would like to focus on 2 issues raised by the critics of CTC (e.g. Ullrich et al. 1999) that apply more generally to the problem of single-cell activity in bacterioplankton. The first is the statement that, as opposed to CTC, other more sensitive methods, such as microautoradiography, suggest that most natural bacterial cells are active. 
Microautoradiography (MAR), one of the earliest single-cell methods developed (Hoppe 1976), is widely held as being the most sensitive technique for enumerating metabolically active bacteria (e.g. Karner \& Fuhrman 1997, Ullrich et al. 1999). This method detects bacteria that are actively engaged in substrate uptake (as measured by a radiolabeled tracer, typically thymidine, an amino acid, or a mixture of amino acids), and therefore presumably active in growth and metabolism. The method is extremely sensitive because the uptake of minute amounts of radioactive substrate can be detected, so it is thought that in general, the threshold of detection of cell activity is also very low. Contrary to what is often assumed about MAR results, however, the number of cells active in substrate uptake seldom represents a dominant fraction of the total assemblage. A systematic survey of the MAR literature for the past $20 \mathrm{yr}$ (Fig. 1) shows that, within natural bacterioplankton communities from a variety of freshwater and marine sites, only 4 of 23 studies reported a mean \% active cells that was greater than $50 \%$, and the average across all studies was $30 \%$. The majority of these studies, it should be noted, were conducted in relatively productive lakes and coastal areas, so these data may be biased towards more active assemblages. Critics of the CTC method are right in pointing out that MAR detects more 'active' bacteria than CTC does, but MAR results certainly do not support the notion that most bacterioplankton cells are uniformly active and growing. What the MAR results do suggest is that there is a large heterogeneity, even within a given system, in the proportion of cells that are apparently active in substrate uptake.

The second issue that we would like to address, which is closely linked to the first one, is the intuition of many that reports of low fractions of 'active' bacteria must, a priori, be wrong, simply because the numbers are low. Corollaries of this intuition are: (1) that methods that result in high proportions of cells scored as positive must be intrinsically better as descriptors of single cell activity in natural bacterioplankton assemblages, and (2) bacterial single cell activity can be effectively described with a single such method. We would like to propose here that: (1) the fact that a method may account for a high proportion of cells does not necessarily imply that it provides a more effective description of the distribution of single-cell activity, and (2) the apparent lack of agreement between methods is the natural consequence of the diversity of physiological states in bacterioplankton, and should be viewed as an advantage rather than a problem.

As an example, one assay that can be used as an index of cell activity involves the detection of cells using oligonucleotide probes and fluorescence in situ hybridization (FISH). The capacity to detect bacterial cells using oligonucleotide probes and FISH is, in part, related to the cell-specific rRNA content (Kerkhof \& Ward 1993, Ruimy et al. 1994), which itself has been suggested as an index of cell activity (Karner \& Fuhrman 1997, Williams et al. 1998). Results of FISH in natural bacterial assemblages show a wide range in the proportion of cells that can be hybridized (less than $5 \%$ to over $100 \%$, Table 1). A recent quantitative review of published reports (from over 60 papers) on the proportion of cells hybridized with the Eubacterial (EUB388) probe shows an average of $56 \%$ of bacterioplankton cells detected using FISH across aquatic ecosystems, and the level of cellular activity may explain at least a portion of this variation (Bouvier \& del Giorgio in press). There have been, however, some recent advances in the FISH protocol, such as the use of polynucleotide probes (Pernthaler et al. 2002), which systematically yield close to $100 \%$ of target cells scored positive. The result of this increase in sensitivity of the FISH method is that these counts are much less dependent on variations in the physiological state of the cells. The fact that most cells can be accounted for by improved FISH protocols does not necessarily mean, however, that these approaches yield an effective description of the distribution of activity at the single cell level, because they do not allow the assessment of the large physiological diversity in bacterioplankton assemblages. At the other end of the spectrum, a method such as culturing, which usually scores less than $1 \%$ of all cells, is also less effective as a descriptor of single-cell activity.

What we would like to emphasize in this Note is that there is no inherent contradiction in the fact that FISH, MAR, CTC and other methods yield different results, and that this, in fact, is what should be expected based on what is known of bacterial growth in aquatic systems. Given the diversity of bacteria that

Table 1. Examples of studies that have used fluorescence in situ hybridization (FISH) in natural bacterioplankton assemblages, with the range in the proportion of cells hybridized with using a Eubacterial probe for different types of systems

\begin{tabular}{|lcl|}
\hline System & $\begin{array}{c}\text { \% cells } \\
\text { hybridized }\end{array}$ & \multicolumn{1}{c|}{ Source } \\
\hline Lakes & $29-70$ & Glöckner et al. (1999) \\
Lakes & $31-78$ & Pernthaler et al. (1998) \\
Estuaries & $51->100$ & Cottrell \& Kirchman (2000) \\
Estuaries & $5-80$ & Bouvier \& del Giorgio (2001) \\
Coastal ocean & $22-78$ & Karner \& Fuhrman (1997) \\
Coastal ocean & $26-70$ & Fuchs et al. (2000) \\
Open ocean & $39-96$ & Glöckner et al. (1999) \\
Open ocean & $55-59$ & Eilers et al. (2000) \\
\hline
\end{tabular}


coexist in natural assemblages, and the fact that not all bacterial populations are growing at the same rates at a given time, it should not be surprising that there is the full range of metabolic states in a given assemblage. In this context, there is also no inherent problem with some methods yielding low proportions of 'reactive' cells, because it is not unrealistic to think that one or a few populations in the assemblage have much higher rates of activity than the rest. Perhaps the biggest criticism that can be targeted at CTC and other activity assays is precisely that most authors have applied these methods in isolation, and in most cases with the assumption that cells are either active or inactive depending on how they score with the technique in question. Such an either/or classification is clearly an over-simplification.

We believe that the problem of describing bacterioplankton single-cell activity should be approached from the viewpoint that there is a nested hierarchy of physiological states within bacterial communities. As such, the different proportions of active cell fractions reported by different methods may not necessarily be incompatible with one another. For example, if a study yields that over $80 \%$ in a given assemblage are reactive to FISH, another that $30 \%$ are responsive to MAR, and yet another that $5 \%$ are responsive to CTC or some other similar method, it would be erroneous to try to decide which of these numbers is the 'right' proportion of active cells in the assemblage. A more logical and meaningful interpretation would be that $80 \%$ of the cells have some level of activity (on the basis of ribosome content), that $37 \%$ of these may be actually taking up substrate at any significant rate based on MAR (although perhaps not all of them growing and dividing), and that $17 \%$ of these MAR-positive cells may have sufficiently high rates of metabolism to be scored positive with CTC.

One aspect of MAR methodology that is often overlooked, but germane to the arguments presented here, is the variability in number of silver grains per bacterium within a given autoradiogram. Briefly, cells are scored as active in MAR when their radioactivity causes the silver grains of a photographic emulsion to develop around the cell (see e.g. Fuhrman \& Azam 1982 for details). Cells are then enumerated as either active (with silver grains) or inactive (without). The number of silver grains per bacterium within a given autoradiogram is, however, highly variable (e.g. Šimek et al. 1989, Grossman 1994). Since the number of silver grains per cell is a function of the amount of radiolabeled substrate incorporated by the cell, this variability is a reflection of the inherent variation in cellspecific metabolic activity present within the bacterial assemblage sampled. Returning to the notion of a nested hierarchy of physiological states, it may be pos- sible that the cells that develop the most number of silver grains are the ones likely to be counted as active by methods such as CTC reduction. Likewise, the brightness of the fluorescent signal obtained with FISH is correlated to RNA content (Oda et al. 2000), and in any given sample it is typical to encounter a wide range of cell fluorescence intensities (del Giorgio \& Bouvier 2002). Again, it may be possible that the CTC method detects only that fraction of cells that have the highest metabolism, and therefore the highest RNA content, and consequently the highest fluorescence intensities detected using FISH.

It is clear that all of the above will remain simple speculation unless we can quantitatively define the thresholds of detection and assign concrete levels of activity to each of the different indices that might be used in parallel. This remains perhaps one of the greatest challenges in this area of microbial ecology, but there has been some recent progress. For example, FISH has been successfully combined with MAR to assess the uptake of specific organic compounds by different phylogenetic bacterial groups (Ouverney \& Fuhrman 1999, Cottrell \& Kirchman 2000), but this approach may eventually be used as a double tracer of cell activity. There are also current attempts to combine MAR with CTC and other physiological probes (J. Gasol, E. \& B. Sherr pers. comm.). Another very promising approach is the flow sorting of cells marked with various probes (Servais et al 2001, Zubkof et al. 2002).

We conclude that the current published data, including MAR and FISH results, do not support the notion that most bacterioplankton cells are uniformly active and growing. This is not to say that one must, therefore, accept the opposite conclusion, that most bacteria are inactive. Rather, these data, combined with other approaches of measuring activity at the single-cell level, should be interpreted within a conceptual model in which there is a continuum of metabolic states in bacterial communities. Different methods have different thresholds and metabolic 'targets' along this continuum, and the lack of agreement among them points to the large range of criteria possible for describing metabolic activity in bacterial communities. While it is clear that we have much to learn about the distribution of metabolic states in situ, it is unlikely that a single method can capture all the physiological diversity present in bacterioplankton assemblages. The discrete, and over-simplistic, notion of 'active' versus 'inactive' cells is not particularly useful in this context, however, and should be replaced by the notion of a continuum of single-cell activity, in which only a combination of different methods will likely yield an effective description of activity within bacterial assemblages. 


\section{LITERATURE CITED}

Almeida MA, Cunha MA, Alcantara F (2001) Physiological responses of marine and brackish water bacterial assemblages in a tidal estuary (Ria de Aveiro, Portugal). Aquat Microb Ecol 25:113-125

Baily CA, Neihof RA, Tabor PS (1983) Inhibitory effect of solar radiation on amino acid uptake in Chesapeake Bay bacteria. Appl Environ Microbiol 46:44-69

Bouvier T, del Giorgio PA (2003) Sensitivity of fluorescence in situ hybridization (FISH): patterns in cell detection in the domain Bacteria. FEMS Microbiol Ecol (in press)

Buck KR, Chavez FP, Campbell L (1996) Basin-wide distributions of living carbon components and the inverted trophic pyramid of the central gyre of the North Atlantic Ocean, summer 1993. Aquat Microbiol Ecol 10:283-298

Bunch JN, Harland RC (1990) Bacterial production in the bottom surface of sea ice in the Canadian subarctic. Can J Fish Aquat Sci 47:1986-1995

Cottrell MT, Kirchman DL (2000) Natural assemblage of marine proteobacteria and members of Cytopha-Flavobacter cluster consuming low- and high-molecular-weight dissolved organic matter. Appl Environ Microbiol 66: 1692-1697

del Giorgio PA, Bouvier T (2002) Linking the physiologic and phylogenetic successions in free-living bacterial communities along an estuarine salinity gradient. Limnol Oceanogr 47:471-486

del Giorgio PA, Prairie YT, Bird DF (1997) Coupling between rates of bacterial production and the abundance of metabolically active bacteria in lakes, counting using CTC reduction and flow cytometry. Microb Ecol 34:144-154

Douglas DJ, Novitsky JA, Fournier RO (1987) Microautoradiography-based enumeration of bacteria with estimates of thymidine-specific growth rates. Mar Ecol Prog Ser 36:91-99

Eilers HJ, Pernthaler J, Glöckner FO, Amann R (2000) Culturability and in situ abundance of pelagic bacteria from the North Sea. Appl Environ Microbiol 66:3004-3051

Fuchs BM, Zubkov MV, Sahm K, Burkill PH, Amann R (2000) Culturability and in situ abundance of pelagic bacteria from the North Sea. Appl Environ Microbiol 66:3044-3051

Fuhrman JA, Azam F (1982) Thymidine incorporation as a measure of heterotrophic bacterioplankton production in marine surface waters: evaluation and field results. Mar Biol 66:1982

García-Cantizano, Calderón-Paz JI, Pedrós-Alió C (1994) Thymidine incorporation in Lake Ciso: problems in estimating bacterial secondary production across oxic-anoxic interfaces. FEMS Microbiol Ecol 14:53-64

Glöckner, FO, Fuchs BM, Amann R (1999) Bacterioplankton compositions of lakes and oceans: a first comparison based on fluorescence in situ hybridization. Appl Environ Microbiol 65:3721-3726

Grossmann S (1994) Bacterial activity in sea ice and open water of the Weddell Sea, Antarctica: a microautoradiographic study. Microb Ecol 28:1-18

Haglund AL, Tornblom E, Bostrom B, Tranvik L (2002) Large differences in the fraction of active bacterial in plankton, sediments, and biofilm. Microb Ecol 43:232-241

Hermansson M, Dahlbäck B (1983) Bacterial activity at the air/water interface. Microb Ecol 9:317-328

Hoppe HG (1976) Determination and properties of actively metabolizing heterotrophic bacteria in the sea investigated by means of micro-autoradiography. Mar Biol 36: 291-302

Hoppe HG (1977) Analysis of actively metabolizing bacterial populations with the autoradiographic method. In: Rheinheimer G (ed) Microbial ecology of a brackish water environment. Springer-Verlag, Berlin, p 179-197

Hoppe HG, Gocke K (1993) The influence of global climate and hydrography on microbial activity in the ocean: results of a N-S Atlantic transect. Proc Int Symp Environ Microbiol, Seoul National University, p 93-110

Joux F, Lebaron P (2000) Use of fluorescent probes to assess physiological functions of bacteria at single-cell level. Microbes Infect 2:1523-1535

Jugnia LB, Richardot M, Debroas D, Sime-Ngando TS, Devaux J (2000) Variations in the number of active bacteria in the euphotic zone of a recently flooded reservoir. Aquat Microb Ecol 22:251-259

Karner M, Fuhrman JA (1997) Determination of active marine bacterioplankton: a comparison of universal 16S rRNA probes, autoradiography, and nucleoid staining. Appl Environ Microbiol 63:1208-1213

Kerkhof L, Ward BB (1993) Comparison of nucleic acid hybridization and fluorometry for measurement of the relationship between RNA/DNA ratio and growth rate in a marine bacterium. Appl Environ Microbiol 59:1303-1309

Marcussen B, Nielsen P, Jeppesen M (1984) Diel changes in bacterial activity determined by means of microautoradiography. Arch Hydrobiol Beih 19:141-149

Meyer-Reil LA (1978) Autoradiography and epifluorescence microscopy combined for the determination of number and spectrum of actively metabolizing bacteria in natural waters. Appl Environ Microbiol 36:506-512

Morita RY (1997) Bacteria in oligotrophic environments. Chapman \& Hall, New York

Nedoma J, Vrba J, Hejzlar J, Šimek K, Straskrabova V (1994) $\mathrm{N}$-acetylglucosamine dynamics in freshwater environments: concentration of amino sugars, extracellular enzyme activities and microbial uptake. Limnol Oceanogr 39:1088-1100

Novitsky JA (1983) Heterotrophic activity throughout a vertical profile of seawater and sediment in Halifax harbor, Canada. Appl Environ Microbiol 45:1753-1760

Oda Y, Slagman SJ, Meijer WG, Forney LJ, Gottschal JC (2000) Influence of growth rate and starvation on fluorescent in situ hybridization of Rhodopseudomonas palustris. FEMS Microbiol Ecol 32:205-213

Ouverney CC, Fuhrman JA (1999) Combined microautoradiography-16s rRNA probe techniques for determination of radioisotope uptake by specific microbial cell types in situ. Appl Environ Microbiol 65:1746-1752

Packard TT (1985) Measurements of electron transport activity in microplankton. Adv Aquat Microbiol 3:207-261

Pedrós-Alió C, Newell SY (1989) Microautoradiographic study of thymidine uptake in brackish waters around Sapelo Island, Georgia, USA. Mar Ecol Prog Ser 55:83-94

Pernthaler J, Glöckner FO, Unterholzner S, Alfreider A, Psenner R, Amann R (1998) Seasonal community and population dynamics of pelagic bacteria and archaea in a high mountain lake. Appl Environ Microbiol 64:4299-4306

Pernthaler A, Preston CM, Pernthaler J, Delong EF, Amann R (2002) Comparison of fluorescently labeled oligonucleotide and polynucleotide probes for the detection of pelagic marine bacteria and archaea. Appl Environ Microbiol 68:661-667

Riemann B, Nielson P, Jeppesen M, Marcussen B, Fuhrman JA (1984) Diel changes in bacterial biomass and growth rates in coastal environments, determined by means of thymidine incorporation into DNA, frequency of dividing cells (FDC), and microautoradiography. Mar Ecol Prog Ser $17: 227-235$ 
Rodriguez GG, Phipps D, Ishiguro K, Ridgway HF (1992) Use of a fluorescent redox probe for direct visualization of actively respiring bacteria. Appl Environ Microbiol 58:1801-1808

Ruimy R, Breittmayer V, Biovin V, Christen R (1994) Assessment of the state of cell activity of individual bacterial cells by hybridization with a ribosomal RNA-targeted fluorescently labeled oligonucleotide probe. FEMS Microbiol Ecol 15:207-213

Servais P, Agogue H, Courties C, Joux F, Lebaron P (2001) Are the actively respiring cells (CTC+) those responsible for bacterial production in aquatic environments? FEMS Microbiol Ecol 1215:1-9

Sherr BF, del Giorgio PA, Sherr EB (1999) Estimating the abundance and single-cell characteristics of respiring bacteria via the redox dye CTC. Aquat Microb Ecol 18: $117-131$

Šimek K, Budejovice C, Fuksa JK (1989) Response in bacterial activity to changing conditions in plankton - probable controlling mechanisms. Arch Hydrobiol Beih 33:239-248

Simon M (1985) Specific uptake rates of amino acids by attached and free-living bacteria in a mesotrophic lake. Appl Environ Microbiol 49:1254-1259

Simon M, Glockner FO, Amann R (1999) Different community structure and temperature optima of heterotrophic picoplankton in various regions of the southern ocean. Aquat Microb Ecol 28:275-284

Smith EM (1998) Coherence of microbial respiration rate and cell-specific bacterial activity in a coastal planktonic community. Aquat Microb Ecol 16:27-35

Editorial responsibility: Jed Fuhrman,

Los Angeles, California, USA
Stevenson LH (1978) A case for bacterial dormancy in aquatic systems. Microb Ecol 4:127-133

Straskrabova V, Šimek K (1984) Total and individual cell uptake of organic substances as a measure of activity of bacterioplankton. Arch Hydrobiol Beih 19:1-6

Tabor PS, Neihof RA (1984) Direct determination of activities for microorganisms of Chesapeake Bay populations. Appl Environ Microbiol 48:1012-1019

Tuomi P, Fagerbakke KM, Bratbak G, Heldal M (1995) Nutritional enrichment of a microbial community: the effects on activity, elemental composition, community structure and virus production. FEMS Microbiol Ecol 16:123-134

Ullrich S, Karrasch B, Hoppe HG, Jeskulke K, Mehrens M (1996) Toxic effects on bacterial metabolism of the redox dye 5-cyano-2,3-ditolyl tetrazolium chloride. Appl Environ Microbiol 62:4587-4593

Ullrich S, Karrasch B, Hoppe HG (1999) Is the CTC dye technique an adequate approach for estimating active bacterial cells? Aquat Microb Ecol 17:207-209

Williams SC, Hong Y, Danavall DCA, Howard-Jones MH, Gibson D, Frischer ME, Verity PG (1998) Distinguishing between living and nonliving bacteria: evaluation of the vital stain propidium iodide and the combined use with molecular probes in aquatic samples. J Microbiol Methods 32:225-236

Zubkov MV, Fuchs BM, Tarran GA, Burkill PH, Amann R (2002) Mesoscale distribution of dominant bacterioplankton groups in the northern North Sea in early summer. Aquat Microb Ecol 29:135-144

Submitted: November 26, 2001; Accepted: October 22, 2002 Proofs received from author(s): February 13, 2003 